\title{
The Endothelial Glycocalyx and Organ Preservation-From Physiology to Possible Clinical Implications for Solid Organ Transplantation
}

\author{
Simon Mathis ${ }^{1}$, Gabriel Putzer ${ }^{1}$, Stefan Schneeberger ${ }^{2}$ and Judith Martini ${ }^{1, *}$ (i) \\ 1 Department of Anaesthesiology and Critical Care Medicine, Medical University of Innsbruck, \\ 6020 Innsbruck, Austria; simon.mathis@i-med.ac.at (S.M.); gabriel.putzer@i-med.ac.at (G.P.) \\ 2 Department of Visceral, Transplant and Thoracic Surgery, Medical University of Innsbruck, \\ 6020 Innsbruck, Austria; stefan.schneeberger@i-med.ac.at \\ * Correspondence: judith.martini@i-med.ac.at
}

check for

updates

Citation: Mathis, S.; Putzer, G.; Schneeberger, S.; Martini, J. The Endothelial Glycocalyx and Organ Preservation-From Physiology to Possible Clinical Implications for Solid Organ Transplantation. Int. J. Mol. Sci. 2021, 22, 4019. https:// doi.org/10.3390/ijms22084019

Academic Editor:

Joan Roselló-Catafau

Received: 10 March 2021

Accepted: 12 April 2021

Published: 13 April 2021

Publisher's Note: MDPI stays neutral with regard to jurisdictional claims in published maps and institutional affiliations.

Copyright: (c) 2021 by the authors. Licensee MDPI, Basel, Switzerland. This article is an open access article distributed under the terms and conditions of the Creative Commons Attribution (CC BY) license (https:/ / creativecommons.org/licenses/by/ $4.0 /)$.

\begin{abstract}
The endothelial glycocalyx is a thin layer consisting of proteoglycans, glycoproteins and glycosaminoglycans that lines the luminal side of vascular endothelial cells. It acts as a barrier and contributes to the maintenance of vascular homeostasis and microperfusion. During solid organ transplantation, the endothelial glycocalyx of the graft is damaged as part of Ischemia Reperfusion Injury (IRI), which is associated with impaired organ function. Although several substances are known to mitigate glycocalyx damage, it has not been possible to use these substances during graft storage on ice. Normothermic machine perfusion (NMP) emerges as an alternative technology for organ preservation and allows for organ evaluation, but also offers the possibility to treat and thus improve organ quality during storage. This review highlights the current knowledge on glycocalyx injury during organ transplantation, presents ways to protect the endothelial glycocalyx and discusses potential glycocalyx protection strategies during normothermic machine perfusion.
\end{abstract}

Keywords: glycocalyx; syndecan-1; heparan sulfate; solid organ transplantation; static cold storage; normothermic machine perfusion

\section{Introduction}

Organ transplantation is the gold standard for the treatment of refractory heart failure, end-stage lung disease, acute and chronic liver failure, and end-stage renal disease [1-4]. Due to organ scarcity, an increasing number of extended-criteria organs are being considered for transplantation [5,6]. These organs are particularly vulnerable and suffer additional damage during retrieval, storage and reperfusion. Although cold storage on ice limits organ damage during transportation and storage, grafts become acidotic. The subsequent reperfusion induces the formation of reactive oxygen species and excessive influx of calcium into the cells, leading to cell swelling, destruction of cell integrity and cell death [7]. Ischemia Reperfusion Injury (IRI), an acute sterile inflammation of the graft after reperfusion, negatively impacts on organ quality and is associated with poorer outcomes in solid organ transplantation [8,9].

The endothelial glycocalyx is an important target in the complex pathophysiological process of IRI. This thin layer, discovered more than 50 years ago [10] lines the inner wall of the endothelium consisting of proteoglycans and glycosaminoglycans. It has been identified as acting as a barrier structure which modulates the adhesion of leukocytes and platelets to the endothelium, participates in coagulation and functions as a mechanotransducer by transmitting shear stress to subendothelial structures [11-14]. Its destruction appears to play a central pathophysiological role in the development of IRI in shock, myocardial infarction, stroke, traumatic blood loss and during solid organ transplantation [15-21]. Various pharmacological and non-pharmacological therapeutics have been 
identified that may prevent glycocalyx destruction or restore glycocalyx integrity [22,23]. Since cold organ storage during transportation minimizes the biological activity of organs, such interventions are not feasible since pharmacological treatment during storage on ice is largely ineffective. In recent years, alternative technologies which create a more physiological environment for grafts have emerged to clinical realization [24]. Normothermic organ perfusion may not only evolve as an ideal organ preservation method in transplantation, but may also offer the possibility to assess and eventually modify glycocalyx integrity and functionality.

This narrative review summarizes the current knowledge on glycocalyx changes during solid organ transplantation and discusses present and potential future options for glycocalyx protection and repair mechanisms.

\section{Structure of the Glycocalyx}

The endothelial glycocalyx is a complex $0.1-1 \mu \mathrm{m}$ thick layer that lines the luminal surface of endothelial cells [22]. As early as 1940, Danielli postulated that a protein layer coats the endothelium [25]. However, direct imaging evidence in electron microscopy was not achieved until a few years later by staining with ruthenium red [10]. Proteoglycans (e.g., syndecans) and glycoproteins form the backbone of this structure and are anchored in the endothelial cells [26,27]. Heparin and chondroitin sulfate glycosaminoglycans covalently bind to these transmembrane proteins, thereby forming a negatively charged matrix where plasma components such as albumin and orosomucoids accumulate [28,29] (Figure 1). Due to vivid crosstalk between different constituents of the glycocalyx, a physiologically active stratum is formed, also referred to as the endothelial surface layer [26,30].

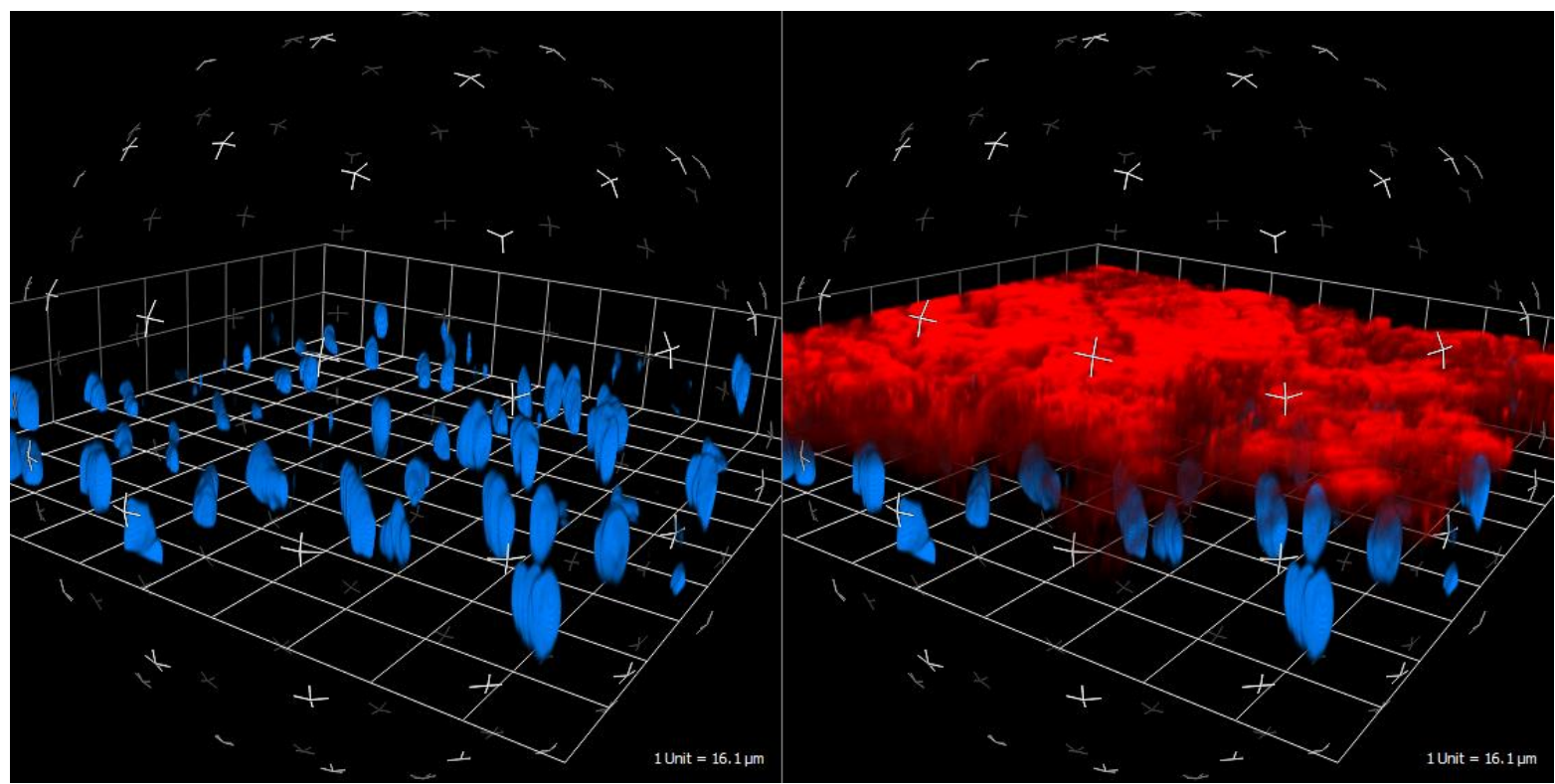

Figure 1. Real time live confocal visualization of the glycocalyx (in red via wheat germ agglutinin) and endothelial cell nuclei (in blue via HOECHST stain). Porcine blood vessel, $40 \times$ water immersion objective.

If the glycocalyx is damaged by different mechanisms, glycocalyx-shedding products can be measured in the plasma. Especially, syndecan- 1 and heparan sulfate are components of the endothelial glycocalyx that have increased plasma concentrations after glycocalyx injury. Different studies have shown that the amount of glycocalyx-shedding products correlates with the severity of the underlying pathological condition [31,32]. Jung et al. showed in cardiogenic shock patients that increased levels of syndecan-1 at admission significantly correlated with poor outcome, thus suggesting that glycocalyx integrity and preservation may be important factors in the maintenance of physiological cardiovascular function [32]. 


\section{Function of the Endothelial Glycocalyx and Pathophysiological Implications}

Even prior to the identification of the biochemical structure of the glycocalyx, the presence of a peripheral layer of plasma surrounding the red blood cell column was observed, and indicated the anatomical location of the glycocalyx [33,34]. The finding by Pries et al., namely that the flow in microvessels is significantly lower than the flow in glass capillaries with the same diameter, demonstrated that the presence of this plasma layer has a significant influence on flow properties of blood in the vascular system [35]. It had previously been noticed, that the haematocrit in capillaries (i.e., the fractional volume of red blood cells within a capillary) was significantly lower than the core haematocrit and the arteriolar haematocrit, which was attributed to the presence of this slow-moving cell-free plasma layer adjacent to the endothelial cell lining [34]. This layer, later identified as the glycocalyx protruding into the vessel lumen, is the reason why red blood cells flow in the center of the vessel [36]. Studies have estimated that the presence of this plasma layer reduces the mean optical haematocrit in microvessels to $25 \%$ of core haematocrit. Further studies have shown that the thickness of this layer can be reduced by treatment with heparinase, which allows the red blood cell column to flow closer to the vascular wall [37]. This increases the width of the red cell column, thereby increasing the fractional volume of red blood cells in the capillary.

It has become increasingly clear that the endothelial glycocalyx mainly regulates vessel wall permeability for fluids and proteins. Contrary to the Starling principle, postulated in the 19th century, fluid exchange via the endothelium is not only driven by the hydrostatic and oncotic pressure prevailing in the vessel and in the interstitium, respectively. Instead, the equilibrium appears to be established by means of the endothelial glycocalyx rather than by the entire capillary wall, thereby reducing fluid filtration into the interstitium [38]. Studies have shown that enzymatic destruction of the endothelial glycocalyx increases hydraulic conductivity leading to the increased clearance of albumin in rat glomeruli and to the formation of myocardial edema [39-41].

Moreover, the endothelial glycocalyx prevents endothelial cells from interacting with cellular blood components. Several experiments have demonstrated that the destruction of the glycocalyx leads to the increased adhesion of red blood cells, leukocytes and platelets to the endothelium, thus leading to perfusion deficits [42,43]. Interestingly, a thick ("healthy") glycocalyx reflects efficient perfusion of the microvascular bed, whereas a thin ("risk") glycocalyx is associated with poor perfusion [44].

The endothelial glycocalyx also acts as a mechanosensor of the vessel wall, transferring mechanical forces, e.g., shear stress, to the endothelial cell. It is well known that endothelial cells produce nitric oxide (NO) in response to shear stress, which induces vasodilatation due to the relaxation of vascular smooth muscle cells and leads to improved perfusion of downstream microvascular beds [45]. Although the exact mechanism of mechanotransduction is not clear, there is evidence that the endothelial glycocalyx is involved [46,47]. This is also supported by several studies which show that NO release is reduced after the glycocalyx is destroyed by hyaluronidase [48].

The endothelial glycocalyx is an enzymatically highly active region. The different endothelial glycosaminoglycans serve as docking points for many plasma-derived molecules such as growth factors, antithrombin, cell adhesion molecules and different cytokines [49]. By binding enzymes and their ligands, the glycocalyx is the anatomical region where numerous enzymatic processes take place $[49,50]$. One of the most important ones is the binding of antithrombin. Antithrombin binds to heparan sulfate anchors in the glycocalyx, leading to a heparin-like effect that prevents clot formation on the endothelial surface and mediates a profibrinolytic and antithrombotic milieu [51]. It has been shown that the degree of destruction of the glycocalyx, due to pathological processes such as sepsis, is a predictive marker for the development of disseminated intravascular coagulation; which is characterized by thrombosis, on the one hand, and coagulopathy with increased bleeding, on the other $[52,53]$. Shedding of the glycocalyx may result in systemic heparin-like effects, resulting in a status of auto-heparinisation, which may play a major role in the 
development of trauma-induced coagulopathy and is also discussed as a potential mechanism for reperfusion-coagulopathy during orthotopic liver transplantation in cirrhotic patients $[13,54,55]$.

\section{The Effect of Solid Organ Transplantation on the Endothelial Glycocalyx}

IRI is a key driving factor for graft damage in heart, lung, liver and kidney transplantation [56-59]. Recent studies have suggested that damage to the endothelial glycocalyx significantly contributes to the development of IRI [21,60,61]. Schiefer et al. found significantly higher plasma levels of syndecan-1 in liver graft recipients after transplantation than before transplantation, indicating destruction of the endothelial glycocalyx [21]. The same study group showed that the levels of syndecan-1 measured in the preservation fluid of liver grafts significantly correlated with hepatic injury markers in the preservation fluid, such as alkaline phosphatase, aspartate aminotransferase and lactate. These findings suggest that glycocalyx degradation occurs in proportion to liver graft injury [62]. Furthermore, it was determined that effluent syndecan- 1 concentrations were greater in recipients who had developed an early allograft dysfunction (EAD) than in patients who had not [62] Taken together, these data suggest a possible role for glycocalyx degradation markers as monitoring parameters for liver graft function early after transplantation.

Another parameter indicating glycocalyx destruction is heparan sulfate. However, Passov and co-workers recently showed that heparan sulfate behaves differently from syndecan-1 during liver transplantation [60]. Whereas syndecan-1 plasma levels strongly increase immediately after reperfusion of the liver graft, plasma levels of heparan sulfate significantly decrease compared to pre-transplant levels. The reason for this finding is still unclear, but the authors assume that heparan sulfate is absorbed into the liver, presumably to restore the destroyed glycocalyx [60].

Destruction of the glycocalyx has also been demonstrated in kidney grafts. After kidney transplantation from donation after circulatory death (DCD) donors, the so-called red blood cell exclusion zone of peritubular capillaries, measured by sidestream darkfield microscopy, is significantly thinner when compared to kidneys from living donors, which indicates destruction of the endothelial glycocalyx during ex situ kidney preservation. In addition, the arteriovenous gradients of syndecan- 1 and heparan sulfate were greater in DCD kidneys than in kidneys from living donors [63].

A significant increase in syndecan-1 and heparan sulfate was also observed in lung transplant recipients. The clinical relevance of glycocalyx damage is indicated by the finding that primary graft dysfunction, defined as $\mathrm{PaO} 2 / \mathrm{FiO} 2<300$, was associated with higher plasma syndecan-1 levels $72 \mathrm{~h}$ after transplantation [61]. Syndecan-1 plasma levels during the first four days after transplantation also showed a correlation with length of ICU stay and duration of ventilation.

Glycocalyx damage in donors predicts poor function after lung transplantation. Sladden et al. found that the only donor factors increasing graft acceptance for lung transplantation were high $\mathrm{PaO} 2$ and low plasma hyaluronan levels; another known glycocalyx destruction parameter. Each $10 \mathrm{ng} / \mathrm{mL}$ decrease in hyaluronan levels in donor plasma was equivalent to a $4 \%$ increase in the likelihood of the graft being accepted for transplantation. In addition, primary graft dysfunction, characterized by $\mathrm{PaO} 2 / \mathrm{FiO} 2<300$ during the first $24 \mathrm{~h}$ after transplantation, was associated with significantly higher syndecan- 1 levels in the respective lung donors [61].

\section{Glycocalyx-Protective and Restoration Strategies}

Based on the large body of literature characterizing the mechanisms of IRI on the endothelial glycocalyx, it seems promising to investigate interventions, aiming to protect or even restore the glycocalyx. Various drugs that may protect and/or restore the endothelial glycocalyx have been tested in animal studies, while human trials are still lacking. Glycocalyx-protective strategies have been investigated during major surgery [64] and the results indicated that preventive measures towards glycocalyx destruction may be effective 
regardless of the mechanism of damage. The following paragraphs will summarize current knowledge about clinical approaches, aiming to protect the glycocalyx during surgery. It is addressed with a focus on the main findings of experimental animal studies to preserve and restore endothelial glycocalyx during IRI of the graft.

In intensive care and perioperative medicine, adequate fluid therapy is a prerequisite for maintaining organ perfusion and oxygenation and for preventing tissue hypoxia. Due to its barrier function, the intact endothelial glycocalyx plays an important role in physiological fluid homeostasis and impedes rapid large transmural fluid shifts from the intravascular to the extravascular compartment. However, the endothelial glycocalyx is particularly sensitive to fluid loading conditions, i.e., hypervolemia [65]. Berg et al. showed that in healthy volunteers the "on top" administration of $1000 \mathrm{~mL}$ of Ringer's acetate led to an increase in plasma hyaluronan levels, thus indicating damage to the glycocalyx [66]. Chappell et al. compared the "on top" administration of $1250 \mathrm{~mL}$ of $6 \%$ hydroxyethyl starch prior to surgery, with patients who underwent normovolemic hemodilution, i.e., by withdrawing $1250 \mathrm{~mL}$ of blood and administering $1250 \mathrm{~mL}$ of $6 \%$ hydroxyethyl starch simultaneously [67]. Hypervolemia, as induced in the first patient group, was associated with a release of atrial natriuretic peptide and an increase in glycocalyx-shedding parameters in the plasma. Atrial natriuretic peptide, in addition to its diuretic and vasodilatory properties, mediates a fluid shift from the intravascular to the extravascular space and induces shedding of the glycocalyx $[68,69]$. Similar results were obtained in a study comparing a liberal fluid regime $(15 \mathrm{~mL} / \mathrm{kg} / \mathrm{h})$ during laparoscopic cholecystectomy and a restrictive fluid regime $(1 \mathrm{~mL} / \mathrm{kg} / \mathrm{h})$. Glycocalyx shedding was significantly increased after liberal fluid administration as compared to the restrictive protocol [65]. In summary, these studies suggest that fluid replacement protocols which are aimed at the maintenance of normovolemia and avoidance of hypervolemia seem to support physiological glycocalyx function.

The question as to which intravenous solution should be used for fluid replacement and volume therapy dates back to the early 1940s and is still controversially discussed [70-76]. In view of their effect on the endothelial glycocalyx, colloids seem to better protect its physiological functioning than crystalloids. Torres et al. showed, in a hemorrhagic shock model in rats, that resuscitation with crystalloids seems to be associated with greater destruction of the glycocalyx than resuscitation with fresh frozen plasma or albumin [77]. Additionally, microvascular barrier function, as assessed by measurements of microvascular permeability, seems to be better preserved with infusions of colloids than with crystalloid solutions [78]. Hence, the type and amount of volume replacement fluids seem to play an important role in maintaining physiological glycocalyx function.

Although none of these studies explicitly refer to solid organ transplantations, it is reasonable to conclude that most of these physiological conditions should be pursued during transplantation.

Hyperglycemia is a common phenomenon in the perioperative phase of transplantation medicine. Besides organ-related specific factors (e.g., destruction of hepatocytes following IRI leading to a systemic influx of glucose during liver transplantation [79], and the high prevalence of impaired glucose tolerance in kidney transplant patients [80]), the administration of glucocorticoids, vasoactive drugs and the surgical-stress reaction lead to metabolic imbalances and hyperglycemia [81-83]. Perioperatively, a blood-glucose level of $5-10 \mathrm{mmol} / \mathrm{L}$ is recommended, which can be achieved with the administration of insulin [84]. It has been shown that persistent hyperglycemia (glucose concentrations of $16 \mathrm{mmol} / \mathrm{L}$ over six hours) induces a reduction in total glycocalyx volume by $50 \%$ in healthy volunteers, while plasma concentrations of hyaluronan significantly increased [85]. Similar results were found in animal and in vitro studies [86-88].

Additionally, the choice of the anesthetic technique seems to have an influence on the integrity of the endothelial glycocalyx. It has already been shown that neuroaxial anesthetic techniques, such as spinal or epidural anesthesia, better preserve glycocalyx structure and function than general anesthesia [89]. However, these techniques are not 
feasible during transplant surgery. When assessing general anesthesia, however, it was shown that the inhaled anesthetic sevoflurane appears to generate glycocalyx-protective properties in various organs. In an IRI model on rat livers, animals were anesthetized with either intravenous ketamine or inhaled sevoflurane before their livers were removed and subsequently reperfused. During reperfusion, glycocalyx-shedding parameters were significantly lower in the perfusate of the sevoflurane group than in the ketamine group, indicating reduced IRI and reduced glycocalyx destruction as confirmed by electron microscopy imaging [90]. Similar results were obtained in a study of lung autotransplantation, where pigs were anaesthetized with either propofol or sevoflurane [91]. After reperfusion, rates of glycocalyx degradation products were higher in the plasma of propofol animals than in animals in the sevoflurane group [91]. A similar effect of sevoflurane on the glycocalyx has also been shown in isolated guinea pig hearts, where the protective effects of sevoflurane were evident regardless of whether sevoflurane was added to the gas mixture before ischemia or after reperfusion [92,93]. In human liver transplantation, however, no positive effects of sevoflurane or other inhalative anesthetics on the glycocalyx have yet been demonstrated [21]. Additionally, other clinical studies comparing the effects of sevoflurane and propofol have shown no benefit so far [94]. Taken together, sevoflurane and propofol may have beneficial effects on the glycocalyx, but the magnitude of these effects does not appear to be significant in major surgery.

\section{Alternative Organ Preservation Strategies and Their Influence on the Glycocalyx}

Static cold storage has been the routine method of organ preservation [95]. During the retrieval procedure, the organ is flushed with a perfusion solution and stored at $0{ }^{\circ} \mathrm{C}$ to $4{ }^{\circ} \mathrm{C}$ on ice. Cooling is intended to suppress metabolic activity [96]. With the increasing use of organs from older donors and organs with reduced organ quality, new storage strategies have been developed for the heart, lung, liver and kidneys [97-102].

A recently developed technique of organ preservation is normothermic machine perfusion (NMP), where the graft is perfused with oxygenated blood and nutrients at normothermic body temperature to provide a physiological environment [99]. This emerging technology for organ preservation allows the actual ischemia time to be minimized and the graft function after organ retrieval to be observed and evaluated [103,104]. In addition to the advantages mentioned above, perfusion of the graft offers the possibility of treating and, ideally, improving organ function during storage [105]. There have been efforts to block IRI pathways by inhibitory RNA, to use stem-cell therapy and to treat infections of the graft during NMP [106-108]. Another approach to maintaining or even improving organ quality during NMP could be to protect and/or restore the glycocalyx. The following paragraphs present several substances whose glycocalyx-protective properties could be used to treat the graft during NMP.

\subsection{Albumin}

Albumin, the main plasma protein, maintains oncotic pressure, binds to hydrophobic ligands in plasma (e.g., drugs) and is an important buffering system. Importantly, it has been shown that albumin also exerts glycocalyx-protective properties. As a carrier of shingosine-1-phosphate, albumin represents a way to attenuate glycocalyx destruction by shingosin-1-phosphate-mediated inhibition of metalloproteases, which play a central role in glycocalyx degradation [109]. Jacob et al. showed in guinea pig hearts that the glycocalyx is better protected by albumin than by saline or hydroxyethyl starch, measured by the extent of edema formation in the myocardium as an indicator of the vascular barrier function of the glycocalyx [78]. Administration of albumin to the traditional preservation solution "histidine-tryptophane-ketoglutarate" (HTK) resulted in significantly decreased syndecan-1 and heparan sulfate levels in the perfusion solution of transplanted guinea pig hearts after four hours of cold ischemic storage as compared to transplanted hearts perfused with HTK preservation solution [110]. Interestingly, right-heart cardiac output was doubled in hearts perfused with albumin/HTK solution compared to hearts perfused 
with pure HTK solution. As right-heart failure is a major early complication following heart transplantation, these results underline the importance of the intact glycocalyx in the pathophysiology of heart transplantation [111]. In summary, albumin appears to exert a glycocalyx-protective effect and protect the graft from interstitial edema in animal studies. Since all novel organ perfusion systems require a perfusion solution, the results of this work could be used to consider albumin as a component of an ideal perfusion solution.

\subsection{Antithrombin}

Several studies have shown that antithrombin, one of the most important endogenous inhibitors of coagulation, exhibits glycocalyx-protective properties. Antithrombin interacts with heparin-like glycosaminoglycans, major components of the glycocalyx, thereby promoting the endothelial release of prostacyclin that in turn inhibits leukocyte activation [22]. Besides these anti-inflammatory characteristics, the tight binding of antithrombin to glycosaminoglycans, prevents destructive enzymes from docking to the glycocalyx, which may preserve its function [112]. Several studies have shown that glycocalyx destruction triggered by TNF alpha or by IRI can be prevented by the administration of antithrombin $[109,113]$. Chappell et al. demonstrated that guinea pig hearts which were pre-treated with antithrombin before a $20 \mathrm{~min}$ warm ischemic period, exhibited significantly lower concentrations of glycocalyx degradation products in the perfusate solution than untreated hearts [113]. Taken together, antithrombin appears to be an important factor in glycocalyx protection. In addition to the interaction with the glycocalyx which prevents clotting and inflammation of the endothelium, antithrombin stabilizes the glycocalyx and protects it from shedding.

\subsection{Glucocorticoids}

Glucocorticoids are known to directly inhibit the production of intracellular reactive oxygen species (ROS) [114]. In fact, steroids suppress the expression of metalloproteases, which seem to play a role in the destruction of glycocalyx after trauma and in sepsis $[112,115,116]$. In an IRI model of an isolated heart, hydrocortisone protected the endothelial glycocalyx, maintained the vascular barrier function and reduced interstitial edema [117]. As glucocorticoids constitute an essential part of immunosuppressive therapy after solid organ transplantation, glycocalyx protection should occur as a positive sideeffect. Administration of glucocorticoids during normothermic machine perfusion could result in further protection of the glycocalyx during organ preservation.

\subsection{Sulodexide}

Sulodexide is a glycosaminoglycan composed of approximately $80 \%$ heparan sulfate and $20 \%$ dermatan sulfate and is approved for the treatment of chronic venous insufficiency and the prevention of recurrent venous thrombosis in certain countries [118-120]. In addition to its anticoagulant properties and inhibition of secretion of inflammatory mediators, it mediates the inhibition of heparinase, which in turn cleaves heparan sulfate thereby destroying the endothelial glycocalyx [121-123]. It has been shown that in septic mice, where the volume of the glycocalyx is significantly reduced, administration of sulodexide accelerated the recovery of the endothelial glycocalyx, reduced vascular permeability and improved survival rates [23]. In another study, sulodexide reduced the infarct size in mice hearts when administered $30 \mathrm{~min}$ after coronary artery occlusion [124]. Although sepsis and IRI present two completely different pathophysiological entities, these results are remarkable as the administration of sulodexide seems to restore the integrity of the glycocalyx, even after the damage has occurred. As damage to the harvested organ occurs during storage and reperfusion, novel therapeutics that improve graft function, even after reperfusion, appear to be a promising approach in transplant medicine to ameliorate acute and chronic graft failure. 


\subsection{Lidocaine}

The amid-type local anesthetic lidocaine has been shown to protect the endothelial glycocalyx. A possible explanation for this finding could be the anti-inflammatory properties of lidocaine, which seem to mitigate IRI [125]. Lidocaine mediates its anti-inflammatory properties by blocking ion channels, thus inhibiting the release of cytokines and histamine from mast cells and basophils [126]. In a pig model for left-sided pneumonectomy and auto-reimplantation of the left caudal lobe of the lung, syndecan-1 and heparan sulfate significantly increased in plasma after transplantation [127]. When the animals were pretreated with lidocaine, glycocalyx destruction was attenuated. Intravenous administration of lidocaine also attenuated the rise of matrix metalloprotease 9 and heparinase after reperfusion, indicating reduced glycocalyx-destructive activity. In summary, perioperative administration of lidocaine protects the glycocalyx in animal studies. Whether an alreadydamaged glycocalyx would benefit from the administration of lidocaine is unclear and needs to be investigated in further studies.

\subsection{Glycocalyx Components}

An intriguing approach to restoring the integrity of the endothelial glycocalyx could be the therapeutic administration of glycocalyx components. In a mouse model of ischemia/reperfusion injury of the cremaster muscle, administration of hyaluronan resulted in glycocalyx repair. Interestingly, this effect was seen regardless of whether hyaluronan was given before or after IRI. This suggests the potential of hyaluronan to prevent glycocalyx destruction, but also its ability to restore the glycocalyx [128]. Other components of the endothelial glycocalyx, e.g., heparan sulfate or sphingosine 1-phosphate, have been successfully used to repair the glycocalyx in cell culture models [129]. The current lack of approval of these substances for human use, however, precludes clinical studies at this time [22].

\section{Conclusions and Perspective}

Several studies indicate that the integrity and function of the glycocalyx is of prime importance in transplantation medicine. Glycocalyx damage, however, occurs during retrieval, storage and reperfusion of the organ. Even though glycocalyx-damaging mechanisms have been recognized, no therapeutic application has been attempted. Given the circumstances of cold storage, interventions aiming to improve certain organ deficits are technically elusive. Novel organ storage techniques such as normothermic perfusion, however, have been recognized as powerful tools which permit the analysis of organ function during storage. Furthermore, normothermic perfusion enables for drug treatment of organs ex situ. Although various substances with a protective or even regenerative effect on the glycocalyx have been identified, they are not yet used in clinical practice. NMP itself reduces IRI and may, therefore, also be associated with the protection of glycocalyx integrity. Treatment with glycocalyx-protective compounds during NMP may further improve graft quality and function during storage and eventually improve the outcome. Therefore, normothermic machine perfusion not only opens the door to organ function assessment, but may also allow organ therapy. The endothelial glycocalyx is a promising target for such interventions, as its integrity seems essential for physiological organ function. Several pharmacological interventions, such as adaptation of the perfusate to optimize microvascular perfusion of the graft, have already been shown to protect and regenerate the endothelial glycocalyx (Figure 2). Given the importance of glycocalyx protection for transplantation medicine, studies assessing the influence of different compounds on glycocalyx protection and regeneration are warranted. 


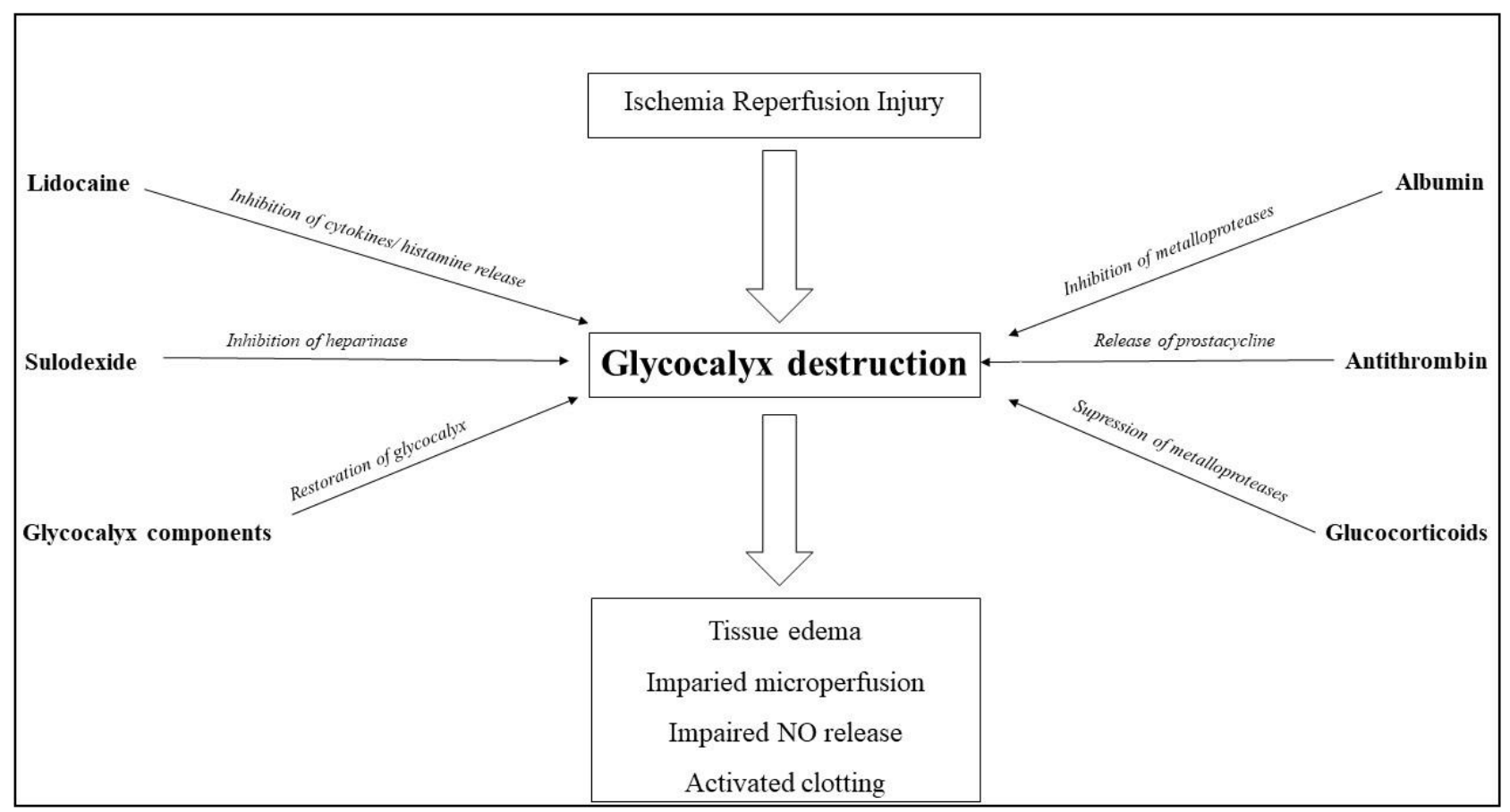

Figure 2. Glycocalyx-protective mechanisms.

Author Contributions: Writing-original draft preparation, S.M. and J.M.; writing-review and editing, G.P., J.M. and S.S. All authors have read and agreed to the published version of the manuscript.

Funding: This research received no external funding.

Institutional Review Board Statement: Not applicable.

Informed Consent Statement: Not applicable.

Acknowledgments: We would like to thank Martin Hermann for preparing and providing the confocal microscopy images.

Conflicts of Interest: The authors declare no conflict of interest.

\section{References}

1. Ammirati, E.; Oliva, F.; Cannata, A.; Contri, R.; Colombo, T.; Martinelli, L.; Frigerio, M. Current indications for heart transplantation and left ventricular assist device: A practical point of view. Eur. J. Intern. Med. 2014, 25, 422-429. [CrossRef]

2. Weill, D.; Benden, C.; Corris, P.A.; Dark, J.H.; Davis, R.D.; Keshavjee, S.; Lederer, D.J.; Mulligan, M.J.; Patterson, G.A.; Singer, L.G.; et al. A consensus document for the selection of lung transplant candidates: 2014-An update from the Pulmonary Transplantation Council of the International Society for Heart and Lung Transplantation. J. Heart Lung Transplant. 2015, $34,1-15$. [CrossRef] [PubMed]

3. O'Leary, J.G.; Lepe, R.; Davis, G.L. Indications for liver transplantation. Gastroenterology 2008, 134, 1764-1776. [CrossRef] [PubMed]

4. Levin, A.; Hemmelgarn, B.; Culleton, B.; Tobe, S.; McFarlane, P.; Ruzicka, M.; Burns, K.; Manns, B.; White, C.; Madore, F.; et al. Guidelines for the management of chronic kidney disease. CMAJ 2008, 179, 1154-1162. [CrossRef] [PubMed]

5. Vodkin, I.; Kuo, A. Extended Criteria Donors in Liver Transplantation. Clin. Liver Dis. 2017, 21, 289-301. [CrossRef]

6. Botha, P. Extended donor criteria in lung transplantation. Curr. Opin. Organ. Transplant. 2009, 14, 206-210. [CrossRef]

7. Kalogeris, T.; Baines, C.P.; Krenz, M.; Korthuis, R.J. Ischemia/Reperfusion. Compr. Physiol. 2016, 7, 113-170. [CrossRef]

8. Stahl, J.E.; Kreke, J.E.; Malek, F.A.; Schaefer, A.J.; Vacanti, J. Consequences of cold-ischemia time on primary nonfunction and patient and graft survival in liver transplantation: A meta-analysis. PLoS ONE 2008, 3, e2468. [CrossRef]

9. Shah, R.J.; Diamond, J.M. Primary Graft Dysfunction (PGD) Following Lung Transplantation. Semin. Respir. Crit. Care Med. 2018, 39, 148-154. [CrossRef]

10. Luft, J.H. Fine structures of capillary and endocapillary layer as revealed by ruthenium red. Fed. Proc. 1966, 25, 1773-1783.

11. Radeva, M.Y.; Waschke, J. Mind the gap: Mechanisms regulating the endothelial barrier. Acta Physiol. 2018, 222. [CrossRef] 
12. Lipowsky, H.H. Role of the Glycocalyx as a Barrier to Leukocyte-Endothelium Adhesion. Adv. Exp. Med. Biol. 2018, 1097, 51-68. [CrossRef]

13. Ostrowski, S.R.; Johansson, P.I. Endothelial glycocalyx degradation induces endogenous heparinization in patients with severe injury and early traumatic coagulopathy. J. Trauma Acute Care Surg. 2012, 73, 60-66. [CrossRef]

14. Tarbell, J.M.; Pahakis, M.Y. Mechanotransduction and the glycocalyx. J. Intern. Med. 2006, 259, 339-350. [CrossRef]

15. Yu, H.; Kalogeris, T.; Korthuis, R.J. Reactive species-induced microvascular dysfunction in ischemia/reperfusion. Free Radic. Biol. Med. 2019, 135, 182-197. [CrossRef]

16. Mulivor, A.W.; Lipowsky, H.H. Inflammation- and ischemia-induced shedding of venular glycocalyx. Am. J. Physiol. Heart Circ. Physiol. 2004, 286, H1672-H1680. [CrossRef]

17. Jackson-Weaver, O.; Friedman, J.K.; Rodriguez, L.A.; Hoof, M.A.; Drury, R.H.; Packer, J.T.; Smith, A.; Guidry, C.; Duchesne, J.C. Hypoxia/reoxygenation decreases endothelial glycocalyx via reactive oxygen species and calcium signaling in a cellular model for shock. J. Trauma Acute Care Surg. 2019, 87, 1070-1076. [CrossRef]

18. Frydland, M.; Ostrowski, S.R.; Møller, J.E.; Hadziselimovic, E.; Holmvang, L.; Ravn, H.B.; Jensen, L.O.; Pettersson, A.S.; Kjaergaard, J.; Lindholm, M.G.; et al. Plasma Concentration of Biomarkers Reflecting Endothelial Cell- and Glycocalyx Damage are Increased in Patients with Suspected ST-Elevation Myocardial Infarction Complicated by Cardiogenic Shock. Shock 2018, 50, 538-544. [CrossRef]

19. DellaValle, B.; Hasseldam, H.; Johansen, F.F.; Iversen, H.K.; Rungby, J.; Hempel, C. Multiple Soluble Components of the Glycocalyx Are Increased in Patient Plasma After Ischemic Stroke. Stroke 2019, 50, 2948-2951. [CrossRef]

20. Rahbar, E.; Cardenas, J.C.; Baimukanova, G.; Usadi, B.; Bruhn, R.; Pati, S.; Ostrowski, S.R.; Johansson, P.I.; Holcomb, J.B.; Wade, C.E. Endothelial glycocalyx shedding and vascular permeability in severely injured trauma patients. J. Transl. Med. 2015, 13, 117. [CrossRef]

21. Schiefer, J.; Lebherz-Eichinger, D.; Erdoes, G.; Berlakovich, G.; Bacher, A.; Krenn, C.G.; Faybik, P. Alterations of Endothelial Glycocalyx During Orthotopic Liver Transplantation in Patients with End-Stage Liver Disease. Transplantation 2015, 99, $2118-2123$. [CrossRef]

22. Becker, B.F.; Chappell, D.; Bruegger, D.; Annecke, T.; Jacob, M. Therapeutic strategies targeting the endothelial glycocalyx: Acute deficits, but great potential. Cardiovasc. Res. 2010, 87, 300-310. [CrossRef]

23. Song, J.W.; Zullo, J.A.; Liveris, D.; Dragovich, M.; Zhang, X.F.; Goligorsky, M.S. Therapeutic Restoration of Endothelial Glycocalyx in Sepsis. J. Pharmacol. Exp. Ther. 2017, 361, 115-121. [CrossRef]

24. Monbaliu, D.; Brassil, J. Machine perfusion of the liver: Past, present and future. Curr. Opin. Organ. Transplant. 2010, 15, 160-166. [CrossRef] [PubMed]

25. Danielli, J.F. Capillary permeability and oedema in the perfused frog. J. Physiol. 1940, 98, 109-129. [CrossRef] [PubMed]

26. Pries, A.R.; Secomb, T.W.; Gaehtgens, P. The endothelial surface layer. Pflugers Arch. 2000, 440, 653-666. [CrossRef] [PubMed]

27. Weinbaum, S.; Tarbell, J.M.; Damiano, E.R. The structure and function of the endothelial glycocalyx layer. Annu. Rev. Biomed. Eng. 2007, 9, 121-167. [CrossRef] [PubMed]

28. Schnitzer, J.E.; Carley, W.W.; Palade, G.E. Specific albumin binding to microvascular endothelium in culture. Am. J. Physiol. 1988, 254, H425-H437. [CrossRef]

29. Schnitzer, J.E.; Pinney, E. Quantitation of specific binding of orosomucoid to cultured microvascular endothelium: Role in capillary permeability. Am. J. Physiol. 1992, 263, H48-H55. [CrossRef]

30. Pries, A.R.; Kuebler, W.M. Normal endothelium. Handb. Exp. Pharmacol. 2006, 1-40. [CrossRef]

31. Rehm, M.; Bruegger, D.; Christ, F.; Conzen, P.; Thiel, M.; Jacob, M.; Chappell, D.; Stoeckelhuber, M.; Welsch, U.; Reichart, B.; et al. Shedding of the endothelial glycocalyx in patients undergoing major vascular surgery with global and regional ischemia. Circulation 2007, 116, 1896-1906. [CrossRef]

32. Jung, C.; Fuernau, G.; Muench, P.; Desch, S.; Eitel, I.; Schuler, G.; Adams, V.; Figulla, H.R.; Thiele, H. Impairment of the endothelial glycocalyx in cardiogenic shock and its prognostic relevance. Shock 2015, 43, 450-455. [CrossRef]

33. Vink, H.; Duling, B.R. Identification of distinct luminal domains for macromolecules, erythrocytes, and leukocytes within mammalian capillaries. Circ. Res. 1996, 79, 581-589. [CrossRef]

34. Klitzman, B.; Duling, B.R. Microvascular hematocrit and red cell flow in resting and contracting striated muscle. Am. J. Physiol. 1979, 237, H481-H490. [CrossRef]

35. Pries, A.R.; Secomb, T.W.; Gessner, T.; Sperandio, M.B.; Gross, J.F.; Gaehtgens, P. Resistance to blood flow in microvessels in vivo. Circ. Res. 1994, 75, 904-915. [CrossRef]

36. Fåhraeus, R. The suspension stability of the blood. Physiol. Rev. 1929, 9, 241-274. [CrossRef]

37. Desjardins, C.; Duling, B.R. Heparinase treatment suggests a role for the endothelial cell glycocalyx in regulation of capillary hematocrit. Am. J. Physiol. 1990, 258, H647-H654. [CrossRef]

38. Adamson, R.H.; Lenz, J.F.; Zhang, X.; Adamson, G.N.; Weinbaum, S.; Curry, F.E. Oncotic pressures opposing filtration across non-fenestrated rat microvessels. J. Physiol. 2004, 557, 889-907. [CrossRef]

39. Adamson, R.H. Permeability of frog mesenteric capillaries after partial pronase digestion of the endothelial glycocalyx. J. Physiol. 1990, 428, 1-13. [CrossRef]

40. Jeansson, M.; Haraldsson, B. Morphological and functional evidence for an important role of the endothelial cell glycocalyx in the glomerular barrier. Am. J. Physiol. Renal Physiol. 2006, 290, F111-F116. [CrossRef] 
41. Van den Berg, B.M.; Vink, H.; Spaan, J.A. The endothelial glycocalyx protects against myocardial edema. Circ. Res. 2003, 92, 592-594. [CrossRef] [PubMed]

42. Vink, H.; Constantinescu, A.A.; Spaan, J.A. Oxidized lipoproteins degrade the endothelial surface layer: Implications for platelet-endothelial cell adhesion. Circulation 2000, 101, 1500-1502. [CrossRef] [PubMed]

43. Lipowsky, H.H.; Sah, R.; Lescanic, A. Relative roles of doxycycline and cation chelation in endothelial glycan shedding and adhesion of leukocytes. Am. J. Physiol. Heart Circ. Physiol. 2011, 300, H415-H422. [CrossRef] [PubMed]

44. Lee, D.H.; Dane, M.J.; van den Berg, B.M.; Boels, M.G.; van Teeffelen, J.W.; de Mutsert, R.; den Heijer, M.; Rosendaal, F.R.; van der Vlag, J.; van Zonneveld, A.J.; et al. Deeper penetration of erythrocytes into the endothelial glycocalyx is associated with impaired microvascular perfusion. PLoS ONE 2014, 9, e96477. [CrossRef]

45. Rubanyi, G.M.; Romero, J.C.; Vanhoutte, P.M. Flow-induced release of endothelium-derived relaxing factor. Am. J. Physiol. 1986, 250, H1145-H1149. [CrossRef]

46. Weinbaum, S.; Zhang, X.; Han, Y.; Vink, H.; Cowin, S.C. Mechanotransduction and flow across the endothelial glycocalyx. Proc. Natl. Acad. Sci. USA 2003, 100, 7988-7995. [CrossRef]

47. Florian, J.A.; Kosky, J.R.; Ainslie, K.; Pang, Z.; Dull, R.O.; Tarbell, J.M. Heparan sulfate proteoglycan is a mechanosensor on endothelial cells. Circ. Res. 2003, 93, e136-e142. [CrossRef]

48. Mochizuki, S.; Vink, H.; Hiramatsu, O.; Kajita, T.; Shigeto, F.; Spaan, J.A.; Kajiya, F. Role of hyaluronic acid glycosaminoglycans in shear-induced endothelium-derived nitric oxide release. Am. J. Physiol. Heart Circ. Physiol. 2003, 285, H722-H726. [CrossRef]

49. Gandhi, N.S.; Mancera, R.L. The structure of glycosaminoglycans and their interactions with proteins. Chem. Biol. Drug Des. 2008, 72, 455-482. [CrossRef]

50. Fromm, J.R.; Hileman, R.E.; Weiler, J.M.; Linhardt, R.J. Interaction of fibroblast growth factor-1 and related peptides with heparan sulfate and its oligosaccharides. Arch. Biochem. Biophys. 1997, 346, 252-262. [CrossRef]

51. Shimada, K.; Kobayashi, M.; Kimura, S.; Nishinaga, M.; Takeuchi, K.; Ozawa, T. Anticoagulant heparin-like glycosaminoglycans on endothelial cell surface. Jpn. Circ. J. 1991, 55, 1016-1021. [CrossRef]

52. Ikeda, M.; Matsumoto, H.; Ogura, H.; Hirose, T.; Shimizu, K.; Yamamoto, K.; Maruyama, I.; Shimazu, T. Circulating syndecan-1 predicts the development of disseminated intravascular coagulation in patients with sepsis. J. Crit. Care 2018, 43, 48-53. [CrossRef]

53. Wada, H.; Thachil, J.; Di Nisio, M.; Mathew, P.; Kurosawa, S.; Gando, S.; Kim, H.K.; Nielsen, J.D.; Dempfle, C.E.; Levi, M.; et al. Guidance for diagnosis and treatment of DIC from harmonization of the recommendations from three guidelines. J. Thromb. Haemost. 2013. [CrossRef]

54. Kettner, S.C.; Gonano, C.; Seebach, F.; Sitzwohl, C.; Acimovic, S.; Stark, J.; Schellongowski, A.; Blaicher, A.; Felfernig, M.; Zimpfer, M. Endogenous heparin-like substances significantly impair coagulation in patients undergoing orthotopic liver transplantation. Anesth. Analg. 1998, 86, 691-695. [CrossRef]

55. Senzolo, M.; Cholongitas, E.; Thalheimer, U.; Riddell, A.; Agarwal, S.; Mallett, S.; Ferronato, C.; Burroughs, A.K. Heparin-like effect in liver disease and liver transplantation. Clin. Liver Dis. 2009, 13, 43-53. [CrossRef]

56. Liu, G.; Zhang, H.; Hao, F.; Hao, J.; Pan, L.; Zhao, Q.; Wo, J. Clusterin Reduces Cold Ischemia-Reperfusion Injury in Heart Transplantation Through Regulation of NF-kB Signaling and Bax/Bcl-xL Expression. Cell Physiol. Biochem. 2018, 45, 1003-1012. [CrossRef]

57. Saidi, R.F.; Kenari, S.K. Liver ischemia/reperfusion injury: An overview. J. Investig. Surg. 2014, 27, 366-379. [CrossRef]

58. Nieuwenhuijs-Moeke, G.J.; Pischke, S.E.; Berger, S.P.; Sanders, J.S.F.; Pol, R.A.; Struys, M.M.R.F.; Ploeg, R.J.; Leuvenink, H.G.D. Ischemia and Reperfusion Injury in Kidney Transplantation: Relevant Mechanisms in Injury and Repair. J. Clin. Med. 2020, 9, 253. [CrossRef]

59. Chen, F.; Date, H. Update on ischemia-reperfusion injury in lung transplantation. Curr. Opin. Organ. Transplant. 2015, 20, 515-520. [CrossRef]

60. Passov, A.; Schramko, A.; Mäkisalo, H.; Nordin, A.; Andersson, S.; Pesonen, E.; Ilmakunnas, M. Graft glycocalyx degradation in human liver transplantation. PLoS ONE 2019, 14, e0221010. [CrossRef]

61. Sladden, T.M.; Yerkovich, S.; Grant, M.; Zhang, F.; Liu, X.; Trotter, M.; Hopkins, P.; Linhardt, R.J.; Chambers, D.C. Endothelial Glycocalyx Shedding Predicts Donor Organ Acceptability and Is Associated with Primary Graft Dysfunction in Lung Transplant Recipients. Transplantation 2019, 103, 1277-1285. [CrossRef]

62. Schiefer, J.; Faybik, P.; Koch, S.; Tudor, B.; Kollmann, D.; Kuessel, L.; Krenn, C.G.; Berlakovich, G.; Baron, D.M.; Baron-Stefaniak, J. Glycocalyx Damage Within Human Liver Grafts Correlates with Graft Injury and Postoperative Graft Function After Orthotopic Liver Transplantation. Transplantation 2020, 104, 72-78. [CrossRef] [PubMed]

63. Snoeijs, M.G.; Vink, H.; Voesten, N.; Christiaans, M.H.; Daemen, J.W.; Peppelenbosch, A.G.; Tordoir, J.H.; Peutz-Kootstra, C.J.; Buurman, W.A.; Schurink, G.W.; et al. Acute ischemic injury to the renal microvasculature in human kidney transplantation. Am. J. Physiol. Renal Physiol. 2010, 299, F1134-F1140. [CrossRef] [PubMed]

64. Brettner, F.; Chappell, D.; Nebelsiek, T.; Hauer, D.; Schelling, G.; Becker, B.F.; Rehm, M.; Weis, F. Preinterventional hydrocortisone sustains the endothelial glycocalyx in cardiac surgery. Clin. Hemorheol. Microcirc. 2019, 71, 59-70. [CrossRef]

65. Belavić, M.; Sotošek Tokmadžić, V.; Fišić, E.; Brozović Krijan, A.; Strikić, N.; Lončarić Katušin, M.; Žunić, J. The effect of various doses of infusion solutions on the endothelial glycocalyx layer in laparoscopic cholecystectomy patients. Minerva Anestesiol. 2018, 84, 1032-1043. [CrossRef] [PubMed] 
66. Berg, S.; Engman, A.; Hesselvik, J.F.; Laurent, T.C. Crystalloid infusion increases plasma hyaluronan. Crit. Care Med. 1994, 22, 1563-1567. [CrossRef] [PubMed]

67. Chappell, D.; Bruegger, D.; Potzel, J.; Jacob, M.; Brettner, F.; Vogeser, M.; Conzen, P.; Becker, B.F.; Rehm, M. Hypervolemia increases release of atrial natriuretic peptide and shedding of the endothelial glycocalyx. Crit. Care 2014, 18, 538. [CrossRef]

68. Potter, L.R.; Yoder, A.R.; Flora, D.R.; Antos, L.K.; Dickey, D.M. Natriuretic peptides: Their structures, receptors, physiologic functions and therapeutic applications. Handb. Exp. Pharmacol. 2009, 341-366. [CrossRef]

69. Bruegger, D.; Jacob, M.; Rehm, M.; Loetsch, M.; Welsch, U.; Conzen, P.; Becker, B.F. Atrial natriuretic peptide induces shedding of endothelial glycocalyx in coronary vascular bed of guinea pig hearts. Am. J. Physiol. Heart Circ. Physiol. 2005, 289, H1993-H1999. [CrossRef]

70. Knotzer, H.; Hasibeder, W.R. In search of the optimal perfusion pressure-does the microcirculation give us the answer? Crit. Care Med. 2009, 37, 2120-2121. [CrossRef]

71. Brunkhorst, F.M.; Engel, C.; Bloos, F.; Meier-Hellmann, A.; Ragaller, M.; Weiler, N.; Moerer, O.; Gruendling, M.; Oppert, M.; Grond, S.; et al. Intensive insulin therapy and pentastarch resuscitation in severe sepsis. N. Engl. J. Med. 2008, 358, 125-139. [CrossRef]

72. Guidet, B.; Martinet, O.; Boulain, T.; Philippart, F.; Poussel, J.F.; Maizel, J.; Forceville, X.; Feissel, M.; Hasselmann, M.; Heininger A.; et al. Assessment of hemodynamic efficacy and safety of $6 \%$ hydroxyethylstarch $130 / 0.4 \mathrm{vs} .0 .9 \% \mathrm{NaCl}$ fluid replacement in patients with severe sepsis: The CRYSTMAS study. Crit. Care 2012, 16, R94. [CrossRef]

73. Patel, A.; Pieper, K.; Myburgh, J.A.; Perkovic, V.; Finfer, S.; Yang, Q.; Li, Q.; Billot, L. Reanalysis of the Crystalloid versus Hydroxyethyl Starch Trial (CHEST). N. Engl. J. Med. 2017, 377, 298-300. [CrossRef]

74. Roberts, I.; Shakur, H.; Bellomo, R.; Bion, J.; Finfer, S.; Hunt, B.; Myburgh, J.; Perner, A.; Reinhart, K. Hydroxyethyl starch solutions and patient harm. Lancet 2018, 391, 736. [CrossRef]

75. Raghunathan, K.; Murray, P.T.; Beattie, W.S.; Lobo, D.N.; Myburgh, J.; Sladen, R.; Kellum, J.A.; Mythen, M.G.; Shaw, A.D.; Group, A.X.I. Choice of fluid in acute illness: What should be given? An international consensus. Br. J. Anaesth. 2014, 113, 772-783. [CrossRef]

76. Perner, A.; Haase, N.; Guttormsen, A.B.; Tenhunen, J.; Klemenzson, G.; Åneman, A.; Madsen, K.R.; Møller, M.H.; Elkjær, J.M.; Poulsen, L.M.; et al. Hydroxyethyl starch 130/0.42 versus Ringer's acetate in severe sepsis. N. Engl. J. Med. 2012, 367, 124-134. [CrossRef]

77. Torres Filho, I.P.; Torres, L.N.; Salgado, C.; Dubick, M.A. Plasma syndecan-1 and heparan sulfate correlate with microvascular glycocalyx degradation in hemorrhaged rats after different resuscitation fluids. Am. J. Physiol. Heart Circ. Physiol. 2016, 310, H1468-H1478. [CrossRef]

78. Jacob, M.; Bruegger, D.; Rehm, M.; Welsch, U.; Conzen, P.; Becker, B.F. Contrasting effects of colloid and crystalloid resuscitation fluids on cardiac vascular permeability. Anesthesiology 2006, 104, 1223-1231. [CrossRef]

79. Han, S.; Sangwook Ko, J.; Jin, S.M.; Man Kim, J.; Choi, S.J.; Joh, J.W.; Hoon Chung, Y.; Lee, S.K.; Gwak, M.S.; Kim, G. Glycemic responses to intermittent hepatic inflow occlusion in living liver donors. Liver Transpl. 2015, 21, 180-186. [CrossRef]

80. Fliser, D.; Pacini, G.; Engelleiter, R.; Kautzky-Willer, A.; Prager, R.; Franek, E.; Ritz, E. Insulin resistance and hyperinsulinemia are already present in patients with incipient renal disease. Kidney Int. 1998, 53, 1343-1347. [CrossRef]

81. Kwon, S.; Hermayer, K.L.; Hermayer, K. Glucocorticoid-induced hyperglycemia. Am. J. Med. Sci. 2013, 345, 274-277. [CrossRef]

82. Barth, E.; Albuszies, G.; Baumgart, K.; Matejovic, M.; Wachter, U.; Vogt, J.; Radermacher, P.; Calzia, E. Glucose metabolism and catecholamines. Crit. Care Med. 2007, 35, S508-S518. [CrossRef]

83. Dungan, K.M.; Braithwaite, S.S.; Preiser, J.C. Stress hyperglycaemia. Lancet 2009, 373, 1798-1807. [CrossRef]

84. Pillinger, N.L.; Kam, P. Endothelial glycocalyx: Basic science and clinical implications. Anaesth. Intensive Care 2017, 45, 295-307. [CrossRef] [PubMed]

85. Nieuwdorp, M.; van Haeften, T.W.; Gouverneur, M.C.; Mooij, H.L.; van Lieshout, M.H.; Levi, M.; Meijers, J.C.; Holleman, F.; Hoekstra, J.B.; Vink, H.; et al. Loss of endothelial glycocalyx during acute hyperglycemia coincides with endothelial dysfunction and coagulation activation in vivo. Diabetes 2006, 55, 480-486. [CrossRef]

86. Lopez-Quintero, S.V.; Cancel, L.M.; Pierides, A.; Antonetti, D.; Spray, D.C.; Tarbell, J.M. High glucose attenuates shear-induced changes in endothelial hydraulic conductivity by degrading the glycocalyx. PLoS ONE 2013, 8, e78954. [CrossRef] [PubMed]

87. Singh, A.; Fridén, V.; Dasgupta, I.; Foster, R.R.; Welsh, G.I.; Tooke, J.E.; Haraldsson, B.; Mathieson, P.W.; Satchell, S.C. High glucose causes dysfunction of the human glomerular endothelial glycocalyx. Am. J. Physiol. Renal Physiol. 2011, 300, F40-F48. [CrossRef]

88. Zuurbier, C.J.; Demirci, C.; Koeman, A.; Vink, H.; Ince, C. Short-term hyperglycemia increases endothelial glycocalyx permeability and acutely decreases lineal density of capillaries with flowing red blood cells. J. Appl. Physiol. 2005, 99, 1471-1476. [CrossRef]

89. Astapenko, D.; Pouska, J.; Benes, J.; Skulec, R.; Lehmann, C.; Vink, H.; Cerny, V. Neuraxial anesthesia is less harmful to the endothelial glycocalyx during elective joint surgery compared to general anesthesia. Clin. Hemorheol. Microcirc. 2019, 72, 11-21. [CrossRef]

90. Li, J.; Yuan, T.; Zhao, X.; Lv, G.Y.; Liu, H.Q. Protective effects of sevoflurane in hepatic ischemia-reperfusion injury. Int. J. Immunopathol. Pharmacol. 2016, 29, 300-307. [CrossRef]

91. Casanova, J.; Simon, C.; Vara, E.; Sanchez, G.; Rancan, L.; Abubakra, S.; Calvo, A.; Gonzalez, F.J.; Garutti, I. Sevoflurane anesthetic preconditioning protects the lung endothelial glycocalyx from ischemia reperfusion injury in an experimental lung autotransplant model. J. Anesth. 2016, 30, 755-762. [CrossRef] 
92. Annecke, T.; Chappell, D.; Chen, C.; Jacob, M.; Welsch, U.; Sommerhoff, C.P.; Rehm, M.; Conzen, P.F.; Becker, B.F. Sevoflurane preserves the endothelial glycocalyx against ischaemia-reperfusion injury. Br. J. Anaesth. 2010, 104, 414-421. [CrossRef]

93. Chen, C.; Chappell, D.; Annecke, T.; Conzen, P.; Jacob, M.; Welsch, U.; Zwissler, B.; Becker, B.F. Sevoflurane mitigates shedding of hyaluronan from the coronary endothelium, also during ischemia/reperfusion: An ex vivo animal study. Hypoxia 2016, 4, 81-90. [CrossRef]

94. Kim, H.J.; Kim, E.; Baek, S.H.; Kim, H.Y.; Kim, J.Y.; Park, J.; Choi, E.J. Sevoflurane did not show better protective effect on endothelial glycocalyx layer compared to propofol during lung resection surgery with one lung ventilation. J. Thorac. Dis. 2018, 10, 1468-1475. [CrossRef]

95. McAnulty, J.F. Hypothermic organ preservation by static storage methods: Current status and a view to the future. Cryobiology 2010, 60, S13-S19. [CrossRef]

96. Southard, J.H.; Belzer, F.O. Organ preservation. Annu. Rev. Med. 1995, 46, 235-247. [CrossRef]

97. Ardehali, A.; Esmailian, F.; Deng, M.; Soltesz, E.; Hsich, E.; Naka, Y.; Mancini, D.; Camacho, M.; Zucker, M.; Leprince, P.; et al. Ex-vivo perfusion of donor hearts for human heart transplantation (PROCEED II): A prospective, open-label, multicentre, randomised non-inferiority trial. Lancet 2015, 385, 2577-2584. [CrossRef]

98. Sanchez, P.G.; Mackowick, K.M.; Kon, Z.N. Current state of ex-vivo lung perfusion. Curr. Opin. Organ. Transplant. 2016, 21, 258-266. [CrossRef]

99. Ravikumar, R.; Jassem, W.; Mergental, H.; Heaton, N.; Mirza, D.; Perera, M.T.; Quaglia, A.; Holroyd, D.; Vogel, T.; Coussios, C.C.; et al. Liver Transplantation After Ex Vivo Normothermic Machine Preservation: A Phase 1 (First-in-Man) Clinical Trial. Am. J. Transplant. 2016, 16, 1779-1787. [CrossRef]

100. Hosgood, S.A.; Nicholson, M.L. First in man renal transplantation after ex vivo normothermic perfusion. Transplantation 2011, 92, 735-738. [CrossRef]

101. Weissenbacher, A.; Hunter, J. Normothermic machine perfusion of the kidney. Curr. Opin. Organ. Transplant. 2017, 22, 571-576. [CrossRef] [PubMed]

102. Nasralla, D.; Coussios, C.C.; Mergental, H.; Akhtar, M.Z.; Butler, A.J.; Ceresa, C.D.L.; Chiocchia, V.; Dutton, S.J.; García-Valdecasas, J.C.; Heaton, N.; et al. A randomized trial of normothermic preservation in liver transplantation. Nature 2018, 557, 50-56. [CrossRef] [PubMed]

103. Cardini, B.; Oberhuber, R.; Fodor, M.; Hautz, T.; Margreiter, C.; Resch, T.; Scheidl, S.; Maglione, M.; Bösmüller, C.; Mair, H.; et al. Clinical Implementation of Prolonged Liver Preservation and Monitoring Through Normothermic Machine Perfusion in Liver Transplantation. Transplantation 2020, 104, 1917-1928. [CrossRef] [PubMed]

104. Watson, C.J.E.; Jochmans, I. From “Gut Feeling” to Objectivity: Machine Preservation of the Liver as a Tool to Assess Organ Viability. Curr. Transplant. Rep. 2018, 5, 72-81. [CrossRef] [PubMed]

105. Dengu, F.; Abbas, S.H.; Ebeling, G.; Nasralla, D. Normothermic Machine Perfusion (NMP) of the Liver as a Platform for Therapeutic Interventions during Ex-Vivo Liver Preservation: A Review. J. Clin. Med. 2020, 9, 1046. [CrossRef] [PubMed]

106. Li, X.; Zhang, J.F.; Lu, M.Q.; Yang, Y.; Xu, C.; Li, H.; Wang, G.S.; Cai, C.J.; Chen, G.H. Alleviation of ischemia-reperfusion injury in rat liver transplantation by induction of small interference RNA targeting Fas. Langenbecks Arch. Surg. 2007, 392, 345-351. [CrossRef] [PubMed]

107. Rigo, F.; De Stefano, N.; Navarro-Tableros, V.; David, E.; Rizza, G.; Catalano, G.; Gilbo, N.; Maione, F.; Gonella, F.; Roggio, D.; et al. Extracellular Vesicles from Human Liver Stem Cells Reduce Injury in an Ex Vivo Normothermic Hypoxic Rat Liver Perfusion Model. Transplantation 2018, 102, e205-e210. [CrossRef]

108. Goldaracena, N.; Spetzler, V.N.; Echeverri, J.; Kaths, J.M.; Cherepanov, V.; Persson, R.; Hodges, M.R.; Janssen, H.L.; Selzner, N.; Grant, D.R.; et al. Inducing Hepatitis C Virus Resistance After Pig Liver Transplantation-A Proof of Concept of Liver Graft Modification Using Warm Ex Vivo Perfusion. Am. J. Transplant. 2017, 17, 970-978. [CrossRef]

109. Chappell, D.; Hofmann-Kiefer, K.; Jacob, M.; Rehm, M.; Briegel, J.; Welsch, U.; Conzen, P.; Becker, B.F. TNF-alpha induced shedding of the endothelial glycocalyx is prevented by hydrocortisone and antithrombin. Basic Res. Cardiol. 2009, 104, 78-89. [CrossRef]

110. Jacob, M.; Paul, O.; Mehringer, L.; Chappell, D.; Rehm, M.; Welsch, U.; Kaczmarek, I.; Conzen, P.; Becker, B.F. Albumin augmentation improves condition of guinea pig hearts after $4 \mathrm{hr}$ of cold ischemia. Transplantation 2009, 87, 956-965. [CrossRef]

111. Talha, S.; Charloux, A.; Piquard, F.; Geny, B. Brain natriuretic peptide and right heart dysfunction after heart transplantation. Clin. Transplant. 2017, 31. [CrossRef]

112. Xu, J.; Kim, G.M.; Ahmed, S.H.; Yan, P.; Xu, X.M.; Hsu, C.Y. Glucocorticoid receptor-mediated suppression of activator protein-1 activation and matrix metalloproteinase expression after spinal cord injury. J. Neurosci. 2001, 21, 92-97. [CrossRef]

113. Chappell, D.; Jacob, M.; Hofmann-Kiefer, K.; Rehm, M.; Welsch, U.; Conzen, P.; Becker, B.F. Antithrombin reduces shedding of the endothelial glycocalyx following ischaemia/reperfusion. Cardiovasc. Res. 2009, 83, 388-396. [CrossRef] [PubMed]

114. Sanner, B.M.; Meder, U.; Zidek, W.; Tepel, M. Effects of glucocorticoids on generation of reactive oxygen species in platelets. Steroids 2002, 67, 715-719. [CrossRef]

115. Ramnath, R.; Foster, R.R.; Qiu, Y.; Cope, G.; Butler, M.J.; Salmon, A.H.; Mathieson, P.W.; Coward, R.J.; Welsh, G.I.; Satchell, S.C. Matrix metalloproteinase 9-mediated shedding of syndecan 4 in response to tumor necrosis factor $\alpha$ : A contributor to endothelial cell glycocalyx dysfunction. FASEB J. 2014, 28, 4686-4699. [CrossRef] 
116. Cui, N.; Wang, H.; Long, Y.; Su, L.; Liu, D. Dexamethasone Suppressed LPS-Induced Matrix Metalloproteinase and Its Effect on Endothelial Glycocalyx Shedding. Mediat. Inflamm. 2015, 2015, 912726. [CrossRef]

117. Chappell, D.; Jacob, M.; Hofmann-Kiefer, K.; Bruegger, D.; Rehm, M.; Conzen, P.; Welsch, U.; Becker, B.F. Hydrocortisone preserves the vascular barrier by protecting the endothelial glycocalyx. Anesthesiology 2007, 107, 776-784. [CrossRef]

118. Masola, V.; Zaza, G.; Onisto, M.; Lupo, A.; Gambaro, G. Glycosaminoglycans, proteoglycans and sulodexide and the endothelium: Biological roles and pharmacological effects. Int. Angiol. 2014, 33, 243-254.

119. Veraldi, N.; Guerrini, M.; Urso, E.; Risi, G.; Bertini, S.; Bensi, D.; Bisio, A. Fine structural characterization of sulodexide. J. Pharm. Biomed. Anal. 2018, 156, 67-79. [CrossRef]

120. Carroll, B.J.; Piazza, G.; Goldhaber, S.Z. Sulodexide in venous disease. J. Thromb. Haemost. 2019, 17, 31-38. [CrossRef]

121. Cosmi, B.; Cini, M.; Legnani, C.; Pancani, C.; Calanni, F.; Coccheri, S. Additive thrombin inhibition by fast moving heparin and dermatan sulfate explains the anticoagulant effect of sulodexide, a natural mixture of glycosaminoglycans. Thromb. Res. 2003, 109, 333-339. [CrossRef]

122. Coccheri, S.; Mannello, F. Development and use of sulodexide in vascular diseases: Implications for treatment. Drug Des. Dev. Ther. 2013, 8, 49-65. [CrossRef] [PubMed]

123. Masola, V.; Onisto, M.; Zaza, G.; Lupo, A.; Gambaro, G. A new mechanism of action of sulodexide in diabetic nephropathy: Inhibits heparanase-1 and prevents FGF-2-induced renal epithelial-mesenchymal transition. J. Transl. Med. 2012, 10, 213. [CrossRef] [PubMed]

124. Lauver, D.A.; Booth, E.A.; White, A.J.; Poradosu, E.; Lucchesi, B.R. Sulodexide attenuates myocardial ischemia/reperfusion injury and the deposition of C-reactive protein in areas of infarction without affecting hemostasis. J. Pharmacol. Exp. Ther. 2005, 312, 794-800. [CrossRef]

125. Schmid, R.A.; Yamashita, M.; Ando, K.; Tanaka, Y.; Cooper, J.D.; Patterson, G.A. Lidocaine reduces reperfusion injury and neutrophil migration in canine lung allografts. Ann. Thorac. Surg. 1996, 61, 949-955. [CrossRef]

126. Yanagi, H.; Sankawa, H.; Saito, H.; Iikura, Y. Effect of lidocaine on histamine release and Ca2+ mobilization from mast cells and basophils. Acta Anaesthesiol. Scand. 1996, 40, 1138-1144. [CrossRef]

127. Rancan, L.; Simón, C.; Sánchez Pedrosa, G.; Aymonnier, K.; Shahani, P.M.; Casanova, J.; Muñoz, C.; Garutti, I.; Vara, E. Glycocalyx Degradation after Pulmonary Transplantation Surgery. Eur. Surg. Res. 2018, 59, 115-125. [CrossRef]

128. Rubio-Gayosso, I.; Platts, S.H.; Duling, B.R. Reactive oxygen species mediate modification of glycocalyx during ischemiareperfusion injury. Am. J. Physiol. Heart Circ. Physiol. 2006, 290, H2247-H2256. [CrossRef]

129. Mensah, S.A.; Cheng, M.J.; Homayoni, H.; Plouffe, B.D.; Coury, A.J.; Ebong, E.E. Regeneration of glycocalyx by heparan sulfate and sphingosine 1-phosphate restores inter-endothelial communication. PLoS ONE 2017, 12, e0186116. [CrossRef] 